\title{
ANALISIS PERSEPSI BENDAHARA PENGELUARAN ATAS ASPEK KEPENTINGAN DAN KINERJA PENGGUNA DAN MITRA PERBANKAN DALAM PENERAPAN KARTU KREDIT PEMERINTAH
}

\author{
Ali Said, Sutiono \\ Pusdiklat Anggaran dan Perbendaharaaan
}

\begin{abstract}
The Indonesian government has implemented government credit card since July 2019. This research provides importance and performance analysis of implementing government credit cards in ministries/agencies of Indonesia. This study collected empirical data from an online questionnaire which was distributed to alumni of the expenditure treasurer training organized by the Budget and Treasury Education and Training Center. The selected samples from 222 respondents, was processed using importance and performance analysis. The results of this empirical research shows the performance of KKP holders and the customer service of KKP issuing banks was still below expectations according to the perception of spending treasurers. KKP holders must be provided with intensive socialization on the use of KKP and customer complaint services at KKP issuing banks must be improved. Other results based on non implementing KKP treasurer perceptions, there are still some obstacles faced by ministries/agencies at the implementation of government credit cards. The results of this study cannot be generalized to the implementation of KKP in Indonesia, because of limited number of respondent samples.
\end{abstract}

\begin{abstract}
Abstrak
Pemerintah Indonesia telah menerapkan metode pembayaran tagihan dari rekanan pemerintah menggunakan uang persediaan kartu kredit pemerintah mulai bulan Juli tahun 2019. Penelitian ini bertujuan untuk menganalisis kepentingan dan kinerja atas penerapan kartu kredit pemerintah pada kementerian/lembaga. Data penelitian diperoleh melalui kuesioner online yang disebar melalui media sosial whatsapp. Responden penelitian merupakan alumni pelatihan bendahara pengeluaran yang diselenggarakan oleh Pusdiklat Anggaran dan Perbendaharaan. Sebagian sampel penelitian yang berjumlah 222 responden diolah menggunakan analisis kepentingan dan kinerja. Hasil penelitian menunjukkan bahwa kinerja pemegang KKP dan layanan bank penerbit KKP masih di bawah harapan menurut persepsi bendahara pengeluaran. Pemegang KKP harus diberikan sosialisasi penggunaan KKP yang memadai dan layanan keluhan pelanggan pada bank penerbit KKP harus ditingkatkan. Selain itu masih ditemukan beberapa kendala yang dihadapi oleh kementerian/lembaga pada saat penerapan kartu kredit pemerintah. Dengan keterbatasan jumlah sampel responden, maka hasil penelitian ini tidak dapat digeneralisasi untuk penerapan KKP di Indonesia.
\end{abstract}

Keywords: Government Credit Card, Important Performance Analysis, Government Treasurer

JEL Classification: $\mathrm{H} 50$ 


\section{PENDAHULUAN}

\section{Latar Belakang}

Indonesia adalah pengguna transaksi tunai terbesar kedua di dunia. Artinya hanya sebagian kecil penduduk yang melakukan transaksi non tunai, atau melalui bank. Bintarto dan Auditya (2018) dalam esainya menyatakan bahwa hanya $36 \%$ penduduk Indonesia yang mempunyai rekening bank. Kemudian jumlah penduduk yang menggunakan kartu kredit hanya 4\% dari total populasi. Adopsi untuk penggunaan transaksi non tunai di Indonesia hanya $10 \%$ dari total transaksi. Beberapa negara di dunia, sudah terlebih dahulu mengimplementasikan pembayaran non tunai dalam transaksi keuangan dalam masyarakatnya.

Pemerintah Indonesia telah melakukan berbagai upaya untuk meningkatkan penggunaan uang non tunai oleh masyarakat. Bank Indonesia juga telah mencanangkan cashless society pada tanggal 14 Agustus 2014 di Jakarta. Gerakan ini dilakukan untuk mendorong masyarakat agar melakukan cashless transaction (Kurniati dan Nugroho, 2019).

Kurniati dan Nugroho (2019) juga memaparkan bahwa Presiden Republik Indonesia mendorong implementasi pembayaran non tunai dengan menerbitkan Perpres Nomor 82 Tahun 2016 tentang Strategi Nasional Keuangan Inklusif. Salah satu kebijakan keuangan inklusif diantaranya adalah layanan keuangan pada sektor pemerintah. Kementerian Keuangan menindaklanjuti peraturan presiden di atas dengan menginisiasi strategi pengelolaan likuiditas keuangan negara dengan instrumen keuangan modern. Diantaranya adalah dengan melakukan modernisasi sistem pembayaran APBN secara non tunai.

Beberapa alat pembayaran tagihan pemerintah non tunai yang sudah diimplementasikan oleh pemerintah adalah kartu debit, internet banking dan perkembangan terkini adalah kartu kredit. Pemerintah menggunakan kartu kredit sebagai alat bayar untuk belanja yang dibebankan pada APBN, yang kemudian disebut KKP. Pembayaran tersebut dipenuhi terlebih dahulu oleh bank penerbit KKP dan akan dilunasi oleh satuan kerja pada waktu yang ditentukan (Pratama dan Salam, 2019).

Pemerintah telah menerapkan penggunaan kartu kredit sebagai alat pembayaran tagihan pemerintah sejak tahun 2017 (Pratama dan Salam, 2019). Pada tahun tersebut telah dilakukan piloting penggunaan kartu kredit pemerintah sebelum diterapkan secara menyeluruh pada semua kementerian/lembaga (Lesmana, 2018).

Uji coba dilakukan dalam dua tahapan. Tahap pertama uji coba penggunaan kartu kredit pemerintah dilaksanakan atas enam satuan kerja pada Kementerian/Sekretariat Negara (1 satker), Kementerian Keuangan (3 satker), PPATK, dan KPK. Uji coba tahap kedua dilakukan pada seluruh satuan kerja vertikal Direktorat Jenderal Perbendaharaan di Kementerian Keuangan. Kedua uji coba tersebut dilaksanakan paling lambat bulan Maret 2018 (Direktorat Jenderal Perbendaharaan, 2018). Penerapan secara menyeluruh penggunaan UP KKP pada satuan kerja Kementerian/Lembaga dilakukan mulai 1 Juli 2019 (Kurniati dan Nugroho, 2019).

Penerapan KKP merupakan upaya pemerintah untuk mempercepat pengembangan cashless society, karena 
mendorong kementerian/lembaga untuk melakukan cashless transaction (Pratama dan Salam, 2019). Konsep cashless society yang sudah diterapkan oleh masyarakat diadopsi dalam sistem pembayaran pemerintah. Perubahan sistem pembayaran tunai menjadi pembayaran non tunai pada pemerintahan mendorong penerapan cashless government (Kurniati, Nugroho dan Saragih, 2019).

Tuntutan digitalisasi dan birokrasi yang transparan dan akuntabel mendorong pemerintah untuk menerapkan cashless government dalam rangka modernisasi pengelolaan keuangan negara. Sistem cashless government di Indonesia ditandai dengan penerbitan kartu kredit pemerintah (Kurniati dan Nugroho, 2019).

Berdasarkan data dari Direktorat Pelaksanaan Anggaran Direktorat Jenderal Perbendaharaan, jumlah transaksi pembayaran tagihan pemerintah yang menggunakan UP KKP hingga 31 Desember 2019 secara nasional adalah Rp739,9 milyar. Jumlah tersebut tersebar pada seluruh wilayah kerja Kanwil Direktorat Jenderal Perbendaharaan di seluruh provinsi. Jumlah transaksi terbesar penggunaan KKP pada tahun 2019 berasal dari Kanwil Direktorat Jenderal Perbendaharaan DKI Jakarta senilai Rp318,5 milyar, Jawa Barat senilai Rp16,5 milyar dan Jawa Timur senilai Rp11,2 milyar. Jumlah transaksi terbesar penggunaan KKP pada tahun 2019 berasal dari Kementerian/Sekretariat Negara senilai Rp77 milyar, Kementerian Hukum dan HAM senilai Rp51 milyar dan Kementerian Keuangan senilai Rp40 milyar. UP KKP digunakan sebagian besar untuk pembayaran perjalanan dinas/travel (39\%), penginapan/hotel (17\%) dan pembelian bahan bakar/BBM (16\%).

Per 31 Desember 2019, baru 10.218 satuan kerja yang sudah menggunakan 31.040 kartu kredit pemerintah dalam transaksi belanjanya (Direktorat Jenderal Perbendaharaan, 2020). Perbankan yang sudah menerbitkan UP KKP adalah BRI, BNI, dan Mandiri. Bank BRI melayani $61 \%$ satuan kerja dengan menerbitkan $41 \%$ jumlah kartu dan menyumbang $21 \%$ nilai transaksi pembayaran dengan UP KKP. Bank BNI melayani $18 \%$ satuan kerja, dengan menerbitkan $40 \%$ jumlah kartu dan berkontribusi sebesar $60 \%$ nilai transaksi. Bank Mandiri melayani $21 \%$ satuan kerja, dengan menerbitkan $19 \%$ jumlah kartu, dan 19\% nilai transaksi.

Kartu kredit pemerintah sudah diterapkan secara menyeluruh pada satuan kerja kementerian/lembaga sejak Juli 2019. Namun penerapan KKP oleh satuan kerja masih menghadapi berbagai kendala. Beberapa kendala tersebut diantaranya adalah kurangnya komunikasi terkait penerapan KKP, kurangnya pemahaman terkait penggunaan $K K P$, permasalahan penerbitan KKP oleh bank penerbit, aspek perpajakan atas transaksi dengan KKP, keterbatasan jumlah EDC merchant pada wilayah kerja KPPN Magelang (Novitasari dan Halim, 2020). Kendala lain ditemukan oleh Yulianti dan Nurhazana (2020) berupa kurang efektifnya penerapan KKP pada KPPN Dumai. Inayah (2020) juga menemukan keterbatasan jumlah EDC pada merchant dan kurangnya sosialisasi dalam rangka penerapan KKP pada wilayah kerja KPPN Blitar. Kendalakendala tersebut yang menyebabkan satuan kerja yang menerapkan KKP 
masih sebesar 20\% hingga 30\% dari jumlah satker pada wilayah kerja KPPN di sekitar Solo dan KPPN Malang.

Berdasarkan fakta dan data tersebut, peneliti melakukan kajian mengenai penerapan kartu kredit pemerintah pada satuan kerja kementerian/lembaga. Penelitian ini bertujuan untuk menganalisis kepentingan dan kinerja tahapan/aspek terkait implementasi KKP menurut persepsi bendahara pengeluaran. Penelitian ini juga dilakukan untuk menganalisis kendala-kendala yang dihadapi oleh bendahara pengeluaran pada saat penerapan KKP.

\section{Rumusan Masalah}

Implementasi KKP pada seluruh satuan kerja kementerian/lembaga diharapkan dapat memberikan kemudahan dalam pembayaran tagihan belanja yang dilakukan oleh satuan kerja. Sebelum menggunakan KKP dalam pembayaran transaksi belanjanya, satuan kerja harus melewati beberapa tahapan. Setiap tahapan dalam implementasi KKP membutuhkan peran para pengguna KKP, baik KPA, PPK, pemegang $K K P$, bendahara pengeluaran maupun administrator KKP. Setiap tahapan berhubungan dengan pihak yang berbeda. Pihak-pihak tersebut antara lain, bank penerbit KKP, Kanwil Direktorat Jenderal Perbendaharaan, KPPN, rekanan, maupun pihak lainnya. Para pengguna KKP sebagai responden yang berhubungan dengan berbagai pihak tersebut pada setiap tahapan maupun aspek yang terkait implementasi KKP merupakan responden penelitian ini.

Para responden tersebut akan dikonfirmasi tingkat kepentingan maupun kinerja yang diperoleh untuk setiap tahapan atau aspek dalam implementasi KKP. Oleh karena itu pertanyaan pertama yang diajukan adalah bagaimana harapan/kepentingan responden terhadap setiap tahapan/aspek dalam implementasi KKP. Pertanyaan kedua adalah bagaimana kinerja yang dirasakan oleh responden terkait tahapan/aspek yang dilakukan oleh para pengguna KKP terkait implementasi KKP. Pertanyaan berikutnya adalah apa saja kendala yang dihadapi dalam penerapan KKP pada kementerian/lembaga.

Penelitian ini membatasi ruang lingkup masalah pada proses implementasi KKP pada periode Juli 2019 hingga Juni 2020. Responden penelitian juga dibatasi hanya bendahara pengeluaran.

\section{TINJAUAN LITERATUR}

Mekanisme pembayaran tagihan atas belanja negara ada dua, yaitu mekanisme pembayaran langsung (LS) dan mekanisme uang persediaan (UP). $\mathrm{Hal}$ ini diatur dalam Peraturan Pemerintah Nomor 45 Tahun 2013 tentang Tata Cara Pelaksanaan APBN pasal 65 dan pasal 66. Pada mekanisme LS pembayaran dilakukan dengan cara transfer atau pemindahbukuan dari rekening kas negara ke rekening penerima tagihan. Pada mekanisme UP pembayaran dilakukan dengan uang persediaan yang dikelola oleh bendahara pengeluaran. Mekanisme UP digunakan jika sifat dan tujuan pembayaran tidak mungkin dilakukan melalui mekanisme LS.

Pada 2018 pemerintah menerapkan mekanisme pembayaran tagihan menggunakan kartu kredit pemerintah 
dengan mengubah Peraturan

Pemerintah Nomor 45 Tahun 2013 menjadi Peraturan Pemerintah Nomor 50 Tahun 2018. Secara teknis penerapan KKP diatur dalam Peraturan Menteri Keuangan Nomor 196 Tahun 2018 tentang Tata Cara Pembayaran dan Penggunaan KKP.

UP KKP merupakan bagian dari uang persediaan yang diberikan kepada bendahara pengeluaran dalam bentuk kartu kredit.

Kartu kredit pemerintah tersebut sesuai dengan ketentuan penggunaan uang persediaan. UP KKP dapat digunakan untuk belanja kebutuhan operasional perkantoran, seperti belanja persediaan, belanja pemeliharaan, belanja sewa, dan belanja modal. Selain itu, UP KKP juga dapat digunakan untuk keperluan perjalanan dinas. Dalam rangka perjalanan dinas, UP KKP dapat digunakan untuk membayar transpor seperti pembelian tiket pesawat, dan penginapan atau membayar hotel.

Untuk perjalanan dinas, KKP dipegang oleh pegawai yang melakukan perjalanan dinas. KKP untuk belanja operasional dipegang oleh pegawai atau pejabat yang menangani pembelian atau pengadaan barang/jasa. Penggunaan KKP untuk diterapkan oleh seluruh kementerian/lembaga mulai diberlakukan tanggal 1 Juli 2019.

Selanjutnya dalam PMK di atas diatur hal-hal sebagai berikut:

a. Organisasi dan Wewenang

Penggunaan KKP

Organisasi dan manajemen yang terlibat dalam penggunaan KKP adalah sebagai berikut.
1) Direktorat
Jenderal
Perbendaharaan
2) Direktorat Pelaksanaan Anggaran
3) Kantor
Wilayah
Ditjen
Perbendaharaan
4) Kantor Pelayanan Perbendaharaan Negara
5) Kuasa Pengguna Anggaran
6) Pejabat Pembuat Komitmen
7) Pejabat Penandatangan SPM
8) Bendahara Pengeluaran
9) Pemegang KKP
10) Administrator KKP
11) Kantor Pusat Bank Penerbit KKP
12) Bank Penerbit KKP

b. Tahapan dalam penerapan KKP Tahapan penerapan KKP berdasarkan PMK tersebut di atas adalah sebagai berikut.

1) Perjanjian Kerja Sama Induk

2) Perjanjian Kerja Sama Satker

3) Penetapan Pemegang KKP dan Administrator KKP

4) Pengajuan KKP

5) Penerbitan KKP

6) Penyerahan dan Penggunaan KKP Alur penggunaan KKP ditingkat satuan kerja mulai dari Perjanjian Kerja Sama antara satuan kerja dengan Bank Penerbit KKP adalah sebagai berikut (Gambar 1):

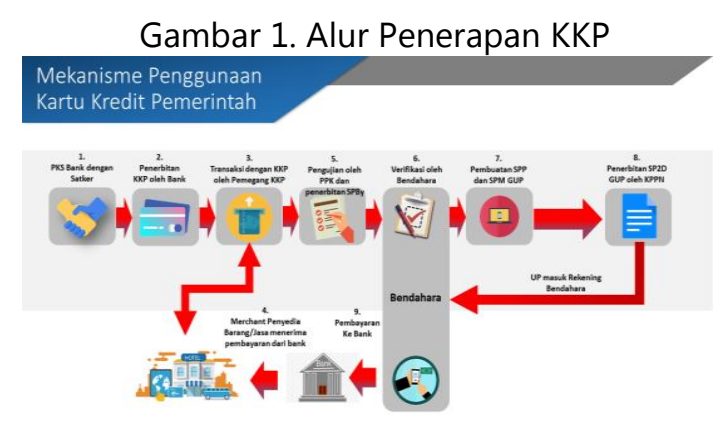

Sumber: Slide focus group discussion Pusdiklat Anggaran dengan Ditjen Perbendaharaan

c. Biaya pelayanan KKP 
Penggunaan KKP dibebaskan berbagai macam biaya. Biaya yang dibebaskan diantaranya:

1) Biaya pembayaran melalui teler, ATM dan e banking

2) Biaya penggantian kartu karena hilang/dicuri atau rusak

3) Biaya penggantian PI

4) Biaya copy billing statement

5) Biaya pencetakan tambahan lembar tagihan

6) Biaya keterlambatan pembayaran

7) Biaya bunga atas tunggakan/ tagihan yang terlambat

8) Biaya penggunaan fasilitas airport lounge yang bekerja sama dengan KKP

Biaya meterai tetap dikenakan berdasarkan Undang Undang Nomor 10 Tahun 2020.

\section{Teori Kepuasan}

Menurut Kotler dan Keller (2009: 164) kepuasan pelanggan akan terjadi jika harapannya atas barang/jasa yang mereka beli sesuai dengan yang mereka harapkan. Seseorang akan merasa puas atau kecewa setelah membandingkan harapan dengan kenyataan yang dia dapatkan. Jika kenyataan yang ia terima jauh lebih rendah dari apa yang ia bayangkan maka ia akan kecewa. Sebaliknya, jika ia mendapatkan lebih dari apa yang ia harapkan maka ia akan senang.

Kepuasan merupakan persepsi seseorang atas kenyataan yang dia dapatkan. Menurut Gerson dan Richard (2001), kepuasan pelanggan akan muncul bila harapannya telah terpenuhi. Pengukuran kepuasan menurut Kotler dan Philip (1998) dapat dilakukan dengan empat metode, yaitu adanya saluran keluhan dan saran, dengan ghost shopping, dengan lost customer analysis, dan survey kepuasan pelanggan.

Sistem yang pertama pelanggan diberikan kesempatan untuk mengungkapkan keluhan dan memberikan saran melalui berbagai media yang disediakan. Kedua, ghost shopping yaitu dengan menugaskan orang lain berperan sebagai pembeli ke toko milik sendiri untuk menguji kualitas pelayanan. Ketiga lost customer survey berarti melakukan analisis atas penyebab pelanggan yang berhenti menerima layanan dan mencari solusi untuk perbaikan selanjutnya. Keempat pengukuran kepuasan pelanggan juga dapat dilakukan dengan melakukan penelitian berupa survey kepuasan pelanggan.

Menurut Selnes dalam Endah dalam Laporan Akhir Survey Opini Stakeholders Kementerian Keuangan dan Institut Pertanian Bogor (2013), kepuasan masyarakat bersifat holistik, meliputi kepuasan secara keseluruhan aspek, dan adanya kesesuaian. antara pelayanan yang diharapkan dengan pelayanan yang diterima selama berinteraksi dengan instansi pemerintah. Sedangkan ketidakpuasan masyarakat bisa disebabkan beberapa hal yaitu, layanan tidak memenuhi harapan, penerimaan layanan yang kurang bersahabat, dan tampilan serta sarana tempat pelayanan yang tidak nyaman.

Mengutip Kennedy dan Young dalam J. Supranto (2011) terdapat tiga indikator untuk mengukur kepuasan pelanggan: say positive things, continue purchasing, dan recommend friend.

Bahia dan Nantel (2000) mengembangkan metode pengukuran baru untuk mengukur kualitas pelayanan bagi industri perbankan yang 
disebut dengan bank service quality (BSQ). Mereka menyempurnakan instrumen pengukuran kualitas pelayanan lain yang masih mengandung kelemahan. BSQ memiliki 6 dimensi sebagai berikut.

Pertama, efektivitas dan Jaminan yaitu kemampuan memberikan pelayanan yang lancar dalam hal birokrasi dan prosedur, kerahasiaan nasabah terjaga, karyawan semakin terlatih dalam melayani nasabah dan memberikan pelayanan sesuai yang dijanjikan.

Kedua, akses yaitu kemampuan meliputi kemudahan untuk dihubungi dan kemudahan kontak dalam memberikan pelayanan, lokasi fasilitas jasa yang mudah dijangkau, jumlah teller/CS yang memadai, antrian cepat dan jumlah ATM yg memadai

Ketiga, harga yaitu biaya yg dikenakan atas pelayanan, biaya yang dikenakan sesuai dengan layanan yang diberikan. Keempat, berwujud yaitu penampilan fisik pegawai, dekorasi, fasilitas kantor yg menarik. Kelima, portofolio jasa yaitu diferensiasi produk/pelayanan. Keenam, keandalan yaitu pelayanan transaksi dengan cepat, tepat dan efisien, koreksi yg cepat dan tepat, pengarsipan yg baik.

\section{Penelitian Sebelumnya}

Hasil penelitian implementasi KKP yang dilakukan Novitasari dan Halim (2020) terhadap satker-satker mitra kerja KPPN Magelang menunjukan bahwa kendala dalam implementasi KKP antara lain komunikasi yang kurang jelas, kurangnya pemahaman pelaksana tentang tata cara implementasi KKP, dan terbatasnya EDC merchant. Penelitian dilakukan menggunakan pendekatan kualitatif dengan rancangan penelitian studi kasus.

Inayah (2020) meneliti efektivitas KKP dalam meminimalisir idle cash bendahara pengeluaran satuan kerja di KPPN Blitar. Hasilnya menunjukkan bahwa penerapan KKP secara efektif dapat mengurangi idle cash uang persediaan.

Yulianti dan Nurhazana (2021) melakukan penelitian tentang efektivitas KKP dalam meningkatkan transparansi keuangan negara pada KPPN Dumai. Hasil penelitian menunjukkan bahwa penerapan KKP pada KPPN Dumai kurang efektif. Penelitian tersebut juga membuktikan bahwa penerapan KKP meningkatkan transparansi pengelolaan keuangan negara.

\section{METODOLOGI PENELITIAN Jenis Penelitian dan Sumber Data}

Jenis penelitian ini merupakan penelitian survey atas fenomena yang terjadi. Pendekatan yang digunakan adalah kuantitatif deskriptif. Penelitian dilakuan atas fenomena baik yang sudah terjadi maupun yang sedang terjadi.

Menurut Nana Syaodih dalam Hamdi \& Bahruddin, 2014) penelitian survey merupakan metode menghimpun informasi berupa opini terhadap sebuah permasalahan tertentu dari berbagai pihak. Fenomena merupakan gejala diluar kebiasaan yang nampak oleh mata dan dapat dijelaskan secara ilmiah. Terkadang fenomena menunjukkan sesuatu akan terjadi (Departemen Pendidikan dan Kebudayaan, 1990). Dalam konteks ini yang dimaksud fenomena adalah hal-hal yang terjadi dalam proses penerbitan dan penggunaan KKP. Baik itu opini, sikap dan perilaku berbagai pihak yang 
terlibat dalam penerbitan dan penggunaan KKP.

Dalam penelitian ini yang diolah adalah data primer dengan dukungan data sekunder. Data primer bersumber dari persepsi bendahara pengeluaran yang berasal dari satuan kerja kementerian/ lembaga. Data sekunder berupa kebijakan dan perkembangan implementasi KKP. Data primer maupun sekunder yang dikumpulkan adalah berdasarkan implementasi KKP pada periode Juli 2019 hingga Juni 2020.

\section{Metode Pengambilan Data}

Pengambilan data kepada responden dilakukan menggunakan kuesioner. Kuisioner berisi pertanyaanpertanyaan terkait berbagai hal yang merupakan indikator atas variable penelitian. Kuesioner dibuat dengan aplikasi google form dan disebarkan secara daring menggunakan media sosial. Responden adalah bendahara pengeluaran yang terlibat dalam penerapan kartu kredit pemerintah. Responden diberikan pertanyaan terkait interaksi mereka pada saat pengajuan KKP dan pada saat belanja kepada rekanan dengan menggunakan KKP. Selain itu, responden juga diberikan pertanyaan mengenai persepsi mereka terkait penerapan KKP.

Dalam pengumpulan informasi peneliti menggunakan kuesioner dengan bentuk pertanyaan terbuka dan pertanyaan tertutup. Kuesioner terbuka disediakan untuk memberikan alternatif jawaban responden yang belum tersedia pada kuesioner tertutup. Kuesioner dengan pertanyaan terbuka memberikan keleluasaan kepada responden dalam memberikan jawaban, misalnya dalam memberikan kritik, saran dan masukan. Kuesioner dengan pertanyaan tertutup, responden diminta memilih jawaban hanya yang disedikan dalam kuesioner. Lingkup pilihan jawaban dibatasi untuk mengurangi ragam jawaban sehingga akan memudahkan peneliti dalam melakukan analisa (Pujihastuti, 2010). Jawaban yang disediakan pun disesuaikan dengan tujuan penelitian.

Pemberian skor pada setiap item pernyataan tersebut menggunakan skala Likert dengan 4 skala. Skala dinyatakan dalam bentuk angka untuk memudahkan pengukuran terhadap indikator variabel. Indikator variabel akan menjadi titik tolak dalam merumuskan pertanyaan-pertanyaan pada kuesioner. Pertanyaan-pertanyaan yang telah disusun ada pada lampiran.

Untuk setiap pertanyaan, responden diminta memilih jawaban atau tanggapan sesuai persepsi mereka. Responden memberi jawaban atau tanggapan dari sisi kepentingan (importance) dan dari sisi kinerja (performance) atau kenyataannya. Setiap pertanyaan disediakan 4 (empat) pilihan jawaban.

\section{Pengembangan Kuesioner}

Kuesioner penelitian dikembangkan berdasarkan tahapan dalam penerapan KKP yang tercantum dalam Peraturan Menteri Keuangan Nomor 196 Tahun 2018 tentang Tata Cara Pembayaran dan Penggunaan Kartu Kredit Pemerintah. Pembuatan KKP dimulai dari perjanjian kerja sama, penetapan pemegang KKP dan administrator $K K P$, pengajuan $K K P$, penerbitan KKP, penyerahan $K K P$, aktivasi KKP, hingga penggunaan KKP. Kuesioner berupa pernyataanpernyataan yang terkait pelayanan dari bank penerbit KKP, dari merchant yang 
melayani pembayaran KKP, pemahaman pengelola keuangan satuan kerja terhadap KKP dan persepsi mereka terhadap penggunaan KKP.

Kuesioner penelitian telah diuji cobakan kepada 30 responden bendahara pengeluaran. Selain itu kuesioner juga disempurnakan oleh pejabat pembuat kebijakan KKP pada Direktorat Jenderal Perbendaharaan. Berdasarkan pilot test atas kuesioner penelitian dan masukan tersebut telah dilakukan penyempurnaan rumusan pertanyaan dalam kuesioner.

\section{Metode Analisis Data}

Metode pengolahan data dalam penelitian ini menggunan IPA (importance performance analysis), yang diperkenalkan oleh Martilla dan James (1977:77-79). Keterkaitan antara kepuasan konsumen dengan kualitas pelayanan barang/jasa dapat diukur dengan IPA. Hubungan tersebut digambarkan dalam bentuk analisis kuadran (Latu dan Everett, 2000). Menurut Martinez, 2003 (dikutip dalam Sultan, at al., 2013:63) secara umum IPA sudah digunakan dalam kajian berbagai bidang karena mudah diaplikasikan dan dipahami dalam pengajuan usulan peningkatan kualitas kinerja.

Dengan IPA setiap pertanyaan memiliki dua jawaban dalam skala Likert. Pilihan pertama merupakan penilaian dari aspek tingkat kepentingannya (importance) dari variable/atribut yang diteliti dilambangkan dengan simbol $Y$, sementara pilihan berikutnya merupakan penilaian dari aspek tingkat kinerja (performance) dari variabel yang diteliti, dan dilambangkan dengan simbol X.
Tingkat kesesuaian antara antara harapan dengan kinerja tersebut dirumuskan dengan $\mathbf{T k i}=\frac{\boldsymbol{X} \boldsymbol{i}}{\boldsymbol{Y} \boldsymbol{x}} \mathbf{1 0 0} \%$

Dimana

Tki = tingkat kesesuaian

$\mathrm{Xi}=$ angka hasil penilaian terhadap kinerja

$\mathrm{Yi}=$ angka penilaian atas harapan pelanggan

(John A. Martila and John C. James, dalam J. Sartono, 2006)

Untuk memetakan kualitas variabel yang dianalisis maka dibuat diagram Kartesius. Dalam diagram Kartesius, sumbu $\mathrm{x}$ menggambarkan tingkat kinerja variabel yang diukur, dan sumbu Y menggambarkan tingkat kepentingan atau harapannya.

Untuk menentukan posisi titik potong pada masing-masing sumbu $x$ dan y digunakan rumus:

$$
\begin{gathered}
\bar{x}=\frac{\sum X i}{n} \\
\bar{Y}=\frac{\sum Y i}{n}
\end{gathered}
$$

Rumus di atas akan menghasilkan dua buah titik pada masing-masing sumbu yang akan menjadi dua garis yang tegak lurus dan berpotongan pada titik $(\overline{\bar{X}}, \overline{\bar{Y}})$. Simbol $\overline{\bar{X}}$ merupakan angka rata-rata tingkat kinerja penggunaan KKP dari seluruh indikator variabel dan $\overline{\bar{Y}}$ adalah angka rata-rata tingkat kepentingan dari seluruh variabel yang penggunaan KKP (Yola dan Budianto, 2013).

Diagram Kartesius merupakan suatu pola yang terdiri dari empat kuadran, seperti pada Gambar 2.

Rumus berikutnya yang digunakan adalah: 


$$
\begin{aligned}
\overline{\bar{X}} & =\frac{\sum_{i=1}^{N} \overline{X \imath}}{K} \\
\overline{\bar{Y}} & =\frac{\sum_{i=1}^{N} \overline{Y \imath}}{K}
\end{aligned}
$$

(J. Supranto, 2006: 242).

dimana, $K=$ jumlah indikator variabel tingkat kinerja (Supranto J, 2006).

Gambar 2. Diagram Kartesius

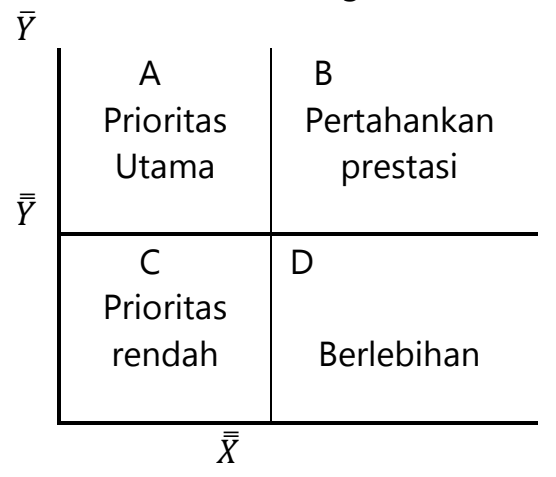

$\bar{X}$

Tanggapan atau persepsi responden atas variabel-variabel yang dinyatakan dalam kuesioner dipetakan dalam masing-masing kuadran dengan penjelasan:

A. Variabel yang menurut responden memiliki kepentingan yang tinggi, namun menghasilkan kinerja yang rendah. Variabel dalam kuadran ini membutuhkan prioritas untuk perbaikan.

B. Variabel yang menurut responden memiliki kepentingan yang tinggi, dan menghasilkan kinerja yang juga tinggi. Variabel dalam kuadran ini harus terus dipertahankan.

C. Variabel yang menurut responden memiliki kepentingan yang rendah, namun menghasilkan kinerja yang juga rendah. Variabel dalam kuadran ini tidak menjadi prioritas untuk diperbaiki.

D. Variabel yang menurut responden memiliki kepentingan yang rendah, namun menghasilkan kinerja yang tinggi. Variabel dalam kuadran ini menunjukkan perlu dilakukan penyesuaian kembali atas penggunaan sumber daya yang berlebihan.

(Supranto, 2006).

\section{HASIL PENELITIAN DAN PEMBAHASAN \\ Profil Responden}

Responden penelitian diperoleh dari data alumni pelatihan Bendahara Pengeluaran yang diselenggarakan oleh Pusdiklat Anggaran dan Perbendaharaan pada periode 2019 sampai dengan pertengahan 2020. Survey dilakukan dengan cara mengirim link google form melalui grup whatsapp maupun whatsapp pribadi responden. Responden mengisi kuesioner secara daring menggunakan link google form kuesioner tersebut. Berdasarkan kuesioner yang disebar kepada lebih dari 2.000 alumni pelatihan, responden yang mengisi lengkap berjumlah 222 orang.

Responden penelitian ini adalah para bendahara pengeluaran pada satuan kerja yang berasal dari 30 kementerian/lembaga. Sampel penelitian ini adalah sebanyak 222 bendahara pengeluaran yang merupakan sebagian kecil dari populasi bendahara pengeluaran diseluruh Indonesia sebanyak 24.768 orang (data DJPb per 2 Desember 2020). 97 responden merupakan bendahara pengeluaran yang satkernya sudah menggunakan KKP dan sisanya 125 bendahara belum menggunakan KKP. 97 responden yang sudah menggunakan KKP selanjutnya diolah menggunakan IPA. 125 responden yang 
belum menggunakan KKP diolah secara deskriptif. Responden yang belum menggunakan KKP juga diberikan pertanyaan tertutup dan terbuka terkait alasan satkernya belum menggunakan KKP.

Kementerian Agama mendominasi sampel dengan 35\% responden. Kementerian Keuangan 11\%, Mahkamah Agung 7\%, Kementerian Hukum dan HAM dan Kementerian Pertanian masing-masing $5 \%$, dan kementerian/lembaga yang lainnya masing-masing di bawah 5\%. Sebaran responden berdasarkan kementerian/lembaga lebih lengkapnya dalam gambar berikut (Gambar 3).

Gambar 3. Diagram Responden Berdasarkan K/L

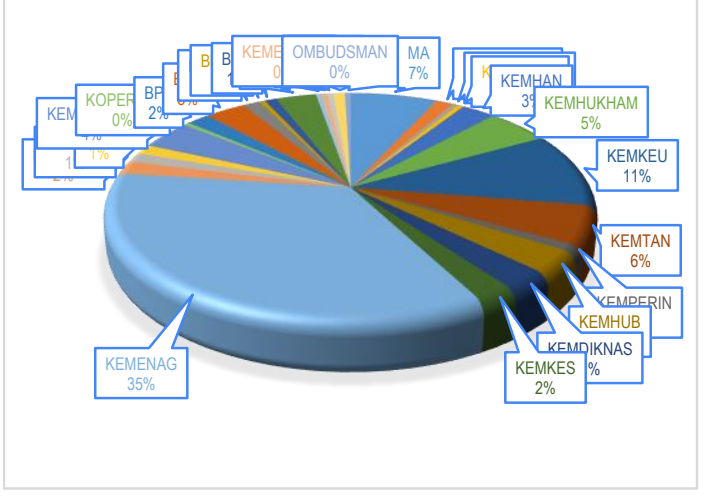

Sumber: data diolah

Berdasarkan waktu penggunaan pertama kali KKP, diperoleh data 52\% responden menggunakan KKP sejak Juli 2019. Sisanya tersebar merata pada periode Agustus 2019 hingga Juni 2020.

Berdasarkan penggunaan KKP diperoleh data $44 \%$ responden sudah menggunakan KKP dan 56\% responden belum menggunakan KKP. Angka pengguna KKP tersebut lebih tinggi dibanding penelitian yang di lakukan oleh Widodo (2020) dalam Maulid dan
Sudibyo (2020) untuk wilayah kerja Solo dan sekitarnya sejumlah 20\%. Angka tersebut juga lebih tinggi dibandingkan penelitian Firdausi (2020) dalam Maulid dan Sudibyo (2020) untuk wilayah kerja KPPN Malang berjumlah 30\% satker yang sudah menggunakan KKP. Responden yang sudah menggunakan KKP akan diolah lebih lanjut dengan metode IPA. Responden yang belum menggunakan KKP akan diolah secara deskriptif.

\section{Analisis Kepentingan dan Kinerja}

Analisis kepentingan dan kinerja di gambarkan dengan diagram Kartesius (Gambar 4). Untuk membuat diagram kartesius harus ditentukan dulu titik potong antara sumbu $X$ yang melambangkan tingkat kinerja dengan sumbu $Y$ yang melambangkan tingkat kepentingan. Titik potong ditentukan dengan rumus:

$$
\begin{aligned}
\overline{\bar{X}} & =\frac{\sum_{i=1}^{N} \overline{X \imath}}{K} \\
\overline{\bar{Y}} & =\frac{\sum_{i=1}^{N} \overline{Y \imath}}{K}
\end{aligned}
$$

Titik potong untuk diagram kartesius bendahara pengeluaran adalah:

Titik potong sumbu $X=\frac{78,247}{22}=$ 3,470009372 
Titik potong sumbu $\mathrm{Y}=\frac{76,340}{22}=$ 3,556701031.

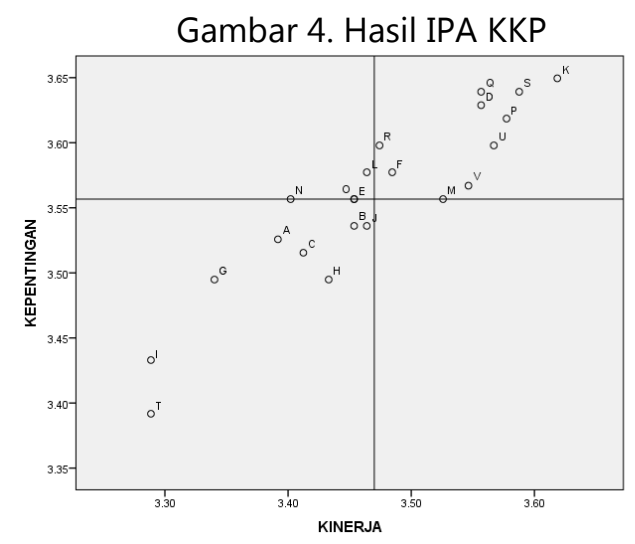

Sumber: data diolah

\section{a. Kuadran 1 (Prioritas Utama)}

Kuadran ini menunjukan variabel $X$ (kinerja) rendah dan variabel $Y$ (kepentingan) tinggi. Responden menganggap atribut ini sangat penting, tapi kinerjanya tidak memuaskan. Ada 4 (empat) atribut yang berada di kuadran 1, yaitu nomor:

1) Pemegang KKP memahami kewenangannya beserta batasannya

2) Pemegang KKP tahu belanja apa saja yang bisa dibayar dengan KKP

3) Tanggapan yang baik dari CS Bank Penerbit KKP terhadap keluhan pengguna

4) Kesopanan petugas CS Bank Penerbit KKP terhadap keluhan pengguna

Keempat atribut ini dipersepsikan mempunyai tingkat kepentingan yang tinggi dalam proses penerapan KKP, tapi dalam pelaksanaannya responden menilai belum sesuai dengan harapan.

Berdasarkan atribut 1 dan 2, responden menilai pengguna KKP kurang memahami penggunaan KKP. Indikatornya adalah penggunaan KKP kurang efektif membantu pelaksanaan belanja satuan kerja. Beberapa kasus yang terjadi misalnya, terdapat pemblokiran KKP yang disebabkan karena penggunaannya diluar peruntukkannya. Kasus kedua adalah KKP yang tidak digunakan oleh satuan kerja karena pemegang KKP adalah kuasa pengguna anggaran (KPA) yang tidak pernah menggunakan KKP. Kasus-kasus tersebut menghambat belanja satuan kerja karena porsi UP KKP yang $40 \%$ tidak digunakan dan tidak bisa juga dikonversi dalam bentuk tunai. Sehingga UP yang digunakan hanya dalam bentuk tunai dengan porsi $60 \%$ dari UP regular yang dikelola bendahara pengeluaran. Temuan terkait kurangnya pemahaman dalam penggunaan KKP sesuai dengan temuan penelitian (Novitasari dan Halim, 2020) dan Inayah (2020).

Atribut 3 dan 4 menunjukkan pelayanan pelanggan dari bank penerbit KKP yang belum memenuhi harapan. KKP merupakan hal yang baru dalam pengelolaan keuangan satuan kerja. Pada saat implementasi kebijakan baru, para pengguna KKP membutuhkan penyesuaian dalam pengelolaan UP KKP. Oleh karena itu satuan kerja membutuhkan pendampingan dalam penyelesaian masalah yang timbul dalam penerapaan KKP. Namun keluhan satuan kerja tersebut belum mendapat respon yang memuaskan dari pihak bank penerbit KKP.

b. Kuadran 2 (Pertahankan Prestasi)

Kuadran ini menunjukan variabel $X$ (kinerja) tinggi dan variabel $Y$ (kepentingan) tinggi juga. Responden menganggap atribut ini sangat penting dan kinerjanya sangat memuaskan. Terdapat 10 (sepuluh) atribut yang berada di posisi ini, yaitu nomor: 
1) PPK dan KPA menunjuk orang yang tepat sebagai pemegang KKP

2) Bank Penerbit KKP merespon dengan baik permohonan penerbitan KKP

3) Pemegang KKP merahasiakan nomor kartu, PIN, CVV dan masa berlaku KKP

4) Secara periodik Pemegang KKP memeriksa kondisi dan rincian transaksi KKP

5) Transaksi yang dilakukan aman

6) Bukti tanda terima pembayaran yang baik

7) Pemotongan nilai nominal yang tepat saat transaksi

8) Penerapan KKP dapat mencegah belanja dengan bukti kuitansi fiktif

9) Penerapan KKP mencegah mark up atas nilai transaksi belanja

10) Penggunaan KKP akan meningkatkan akuntabilitas dan transparansi dalam pengelolaan keuangan satker.

Kesepuluh atribut ini harus dipertahankan, karena responden menilai bahwa atribut-atribut ini sangat penting dalam proses penerapan KKP, dan kinerja yang dirasakan oleh responden sudah sesuai dengan harapan.

Temuan dalam atribut pada kuadran 2 ini mendukung hasil penelitian Yulianti dan Nurhazana (2020) yang menyatakan bahwa penggunaan KKP dapat meningkatkan transparansi pengelolaan keuangan negara.

c. Kuadran 3 (Prioritas Rendah)

Kuadran ini menunjukan variabel $X$ (kinerja) rendah dan variabel $Y$ (kepentingan) rendah. Responden menganggap atribut ini tidak penting dan kinerjanya tidak memuaskan.

Terdapat 8 (delapan) atribut yang berada pada kategori ini, yaitu nomor:
1) Saya mendapatkan sosialisasi tentang KKP

2) Pegawai bank tidak mempersulit PKS dari satker

3) Pegawai bank menandatangani PKS tepat waktu

4) Verifikasi oleh Bank Penerbit KKP atas surat permohonan penerbitan KKP dan dokumen pendukungnya tidak melebihi 6 hari kerja

5) KKP disampaikan kepada KPA melalui sarana pengiriman tercepat

6) KKP disampaikan 1 hari kerja setelah diterbitkan

7) Pemegang KKP memahami isi surat perjanjian penggunaan KKP

8) Penerapan KKP memudahkan pekerjaan bendahara dalam pengelolaan UP

Kedelapan atribut ini dianggap kurang penting terhadap penerbitan dan penerapan KKP, jadi tidak perlu mendapat prioritas yang berlebihan terhadap atribut ini.

d. Kuadran 4 (Berlebihan)

Kuadran ini menunjukan variable $X$ (kinerja) tinggi dan variabel $Y$ (kepentingan) rendah. Responden menganggap atribut ini tidak penting tapi menghasilkan kinerja yang sangat memuaskan.

\section{Analisis Satker yang belum menggunakan KKP}

Berdasarkan kuesioner yang diterima secara daring, diperoleh 125 responden yang satuan kerjanya belum menggunakan KKP. Kementerian Agama mendominasi dengan $45 \%$ responden. $55 \%$ responden yang belum menggunakan KKP tersebar pada 19 kementerian/lembaga lainnya.

Responden yang satuan kerjanya belum menggunakan KKP, 31\% masih dalam proses di bank penerbit KKP, 22\% 
beralasan barang dan jasa yang dibutuhkan oleh satuan kerja tidak tersedia pada rekanan yang memiliki fasilitas EDC. 20\% responden beralasan tidak ada rekanan yang menyediakan fasilitas EDC dan $10 \%$ responden beralasan kebijakan pimpinan untuk tidak menggunakan KKP. 5\% belum ada sosialisasi, $6 \%$ tidak bisa memiliki dana nonbudgeter dan 6\% sisanya dengan alasan beragam. Terkait dengan ketersediaan fasilitas EDC, temuan tersebut sejalan dengan temuan penelitian Kurniati, Nugroho dan Saragih (2019), (Novitasari dan Halim, 2020) dan Inayah (2020).

Sikap responden yang mendukung penggunaan KKP adalah 2,98. Penerapan KKP dapat mencegah transaksi belanja fiktif adalah 3,26. Penerapan KKP akan membantu pekerjaan bendahara pengeluaran dalam pengelolaan UP adalah 2,78. Penerapan KKP akan menghilangkan transaksi markup adalah 3,21. Penggunaan KKP akan meningkatkan akuntabilitas dan transparansi adalah 3,18 .

\section{KESIMPULAN DAN SARAN}

Kesimpulan yang dapat diambil dari penelitian ini adalah:

Menurut persepsi bendahara pengeluaran yang sudah menggunakan $\mathrm{KKP}$, para pemegang KKP belum memahami kewenangan dan batasan sebagai pengguna KKP. Selain itu, pemegang KKP juga belum mengetahui belanja-belanja yang dapat dibayarkan menggunakan KKP. Menurut bendahara pengeluaran, kedua hal tersebut sangat penting dalam penggunaan KKP namun kinerjanya belum sesuai dengan harapan bendahara pengeluaran.
Bendahara pengeluaran yang sudah menerapkan KKP juga memberikan persepsi pelayanan bank penerbit KKP yang belum memenuhi harapan bendahara. Pelayanan tersebut adalah tanggapan customer service atas permasalahan KKP dan sikap mereka ketika memberikan solusi terhadap permasalahan tersebut.

Bendahara pengeluaran yang belum menerapkan KKP menghadapi kendala terkait proses penerbitan KKP, ketersediaan EDC, belum ada sosialisasi, maupun kendala yang lainnya. Selain itu juga terdapat alasan kebijakan pimpinan satker maupun pertimbangan dana nonbudgeter.

Berdasarkan temuan yang terdapat pada kuadran 1, Direktorat Jenderal Perbendaharaan perlu melakukan upaya untuk meningkatkan pemahaman para pemegang KKP terkait kewenangan dan dan batasannya. Peningkatan pemahaman ini bisa dilakukan dengan mengundang biro keuangan kementerian/lembaga dalam sosialisasi penggunaan UP KKP. Selanjutnya kantor pusat kementerian/lembaga meneruskan kepada para pemegang KKP seluruh satuan kerja di bawahnya.

Selanjutnya Direktorat Jenderal Perbendaharaan dapat melibatkan BPPK c.q. Pusdiklat Anggaran dan Perbendaharaan untuk menyelenggarakan e-learning terkait dengan penggunaan KKP dalam pengelolaan keuangan satuan kerja. Selain itu unit vertikal Direktorat Jenderal Perbendaharaan juga dapat melakukan sosialisasi langsung kepada satuan kerja kementerian/lembaga di daerah. Dalam kondisi pandemi Covid19 saat ini, beragam saluran daring dapat digunakan untuk meningkatkan pengetahuan dan pemahaman 
pemegang KKP dalam implementasi KKP. Kanwil DJPb dan KPPN dapat memberikan edukasi secara langsung kepada satker mitra kerjanya dalam bentuk bimbingan teknis atau konsultasi secara online. Hal tersebut sejalan dengan saran penelitian Maulid dan Sudibyo (2020).

Untuk meningkatkan layanan KKP pada bank penerbit KKP, Direktorat Jenderal Perbendaharaan juga perlu mendorong kantor pusat bank penerbit KKP agar mempercepat kantor cabang bank di daerah-daerah dalam memberikan layanan penggunaan KKP yang lebih optimal, khususnya bagi satker-satker di daerah yang berhubungan dengan kantor cabang bank penerbit KKP. Salah satu dimensi yang harus ditingkatkan oleh bank penerbit KKP adalah kualitas layanan berupa efektivitas dan jaminan perbankan yang diberikan kepada pelanggan. Khususnya terkait layanan customer service bank ketika mengatasi keluhan atas permasalahan KKP dan sikapnya dalam menghadapi satuan kerja. Direktorat Jenderal Perbendaharaan bisa membuat saluran pengaduan khusus untuk menampung permasalahan terkait penerapan KKP. Media saluran yang digunakan dapat bervariatif namun saling terintegrasi, sehingga satuan kerja mendapatkan solusi atas keterlambatan penerbitan $K K P$, maupun pengenaan biaya atas transaksi yang menggunakan KKP, maupun permasalahan yang lainnya dengan cara yang efektif.

Selain itu, Direktorat Jenderal Perbendaharaan dapat mendorong bank penerbit KKP untuk memperluas infrastruktur penggunaan KKP di daerah-daerah agar cashless government lebih cepat terwujud. Salah satu upaya yang dapat ditempuh adalah dengan penambahan mesin EDC pada merchant/rekanan dengan insentifinsentif tertentu. Penambahan penggunaan mesin EDC pada rekanan akan mengoptimalkan penggunaan KKP.

\section{KETERBATASAN PENELITIAN}

Penelitian ini memiliki beberapa keterbatasan. Pertama, sampel yang digunakan belum mewakili seluruh kementerian/lembaga, yaitu hanya 35\% dari $86 \quad$ kementerian/lembaga. Responden juga belum mewakili seluruh wilayah di Indonesia. Penelitian selanjutnya dapat menggunakan responden yang dapat merepresentasikan populasi pengguna KKP di seluruh kementerian/lembaga. Penelitian selanjutnya juga dapat menggunakan responden pada seluruh propinsi dan kabupaten di Indonesia, sehingga dapat diperbandingkan kondisi penerapan KKP per wilayah.

Kedua, sampel hanya dibatasi pada persepsi responden bendahara pengeluaran. Penelitian selanjutnya perlu melibatkan responden yang menjabat sebagai kuasa pengguna anggaran, pejabat pembuat komitmen, pemegang KKP, admin KKP maupun pejabat lainnya yang terlibat dalam proses implementasi KKP. Dengan responden yang lebih lengkap akan diperoleh hasil penelitian KKP yang lebih komprehensif.

Ketiga, penelitian ini juga belum melibatkan responden di luar satuan kerja yang berpengaruh dalam implementasi KKP, yaitu bank penerbit KKP, merchant/rekanan penyedia barang dan jasa dan KPPN serta Kanwil Ditjen Perbendaharaan. Penelitian 
selanjutnya dapat melibatkan perbankan, rekanan maupun pihak lain yang terkait penerapan KKP agar dihasilkan penelitian yang lebih baik.

Dengan keterbatasan tersebut, maka hasil penelitian ini tidak dapat digeneralisasi untuk penerapan KKP di Indonesia.

Penelitian ini juga belum mendalami faktor-faktor penyebab yang menjadi kendala dalam implementasi KKP pada kementerian/lembaga. Penelitian selanjutnya dapat menggali lebih dalam dan dapat menggunakan metode lain selain IPA sehingga dapat memberikan rekomendasi yang lebih baik agar penerapan cashless government di Indonesia mencapai tujuan yang diharapkan. Semoga penelitian ini dapat memberikan nilai tambah dalam pengembangan literatur akademis terkait penerapan KKP di Indonesia.

\section{REFERENSI}

Bahia, K. \& Nantel, J. (2000). A realiable and valid measurement scale for the perceive service quality of banks. International Journal of Bank Marketing. 18(2), 87.

Bank Indonesia. (2014). Bank Indonesia Mencanangkan Gerakan Nasional Non Tunai. Siaran Pers, No. 16/58/Dkom.

Bintarto, E. (2018). Fintech dan Cashless Society: Sebuah Revolusi Pendongkrak Ekonomi Kerakyatan. Essay Booklet; The Transformative Power of Fintech. Himma UGM.

Departemen Pendidikan dan Kebudayaan. (1990). Kamus Besar Bahasa Indonesia. Jakarta: Penerbit Balai Pustaka.
Direktur Jenderal Perbendaharaan. (2018). Buku Pintar Kartu Kredit Pemerintah Jilid \#1. Diakses dari https://djpb.kemenkeu.go.id/

Direktur Jenderal Perbendaharaan. (2019) Buku Pintar Kartu Kredit Pemerintah Jilid \#2. Diakses dari http://www.djpb.kemenkeu.go.id

Direktur Jenderal Perbendaharaan. (2020). Slide yang disampaikan pada Focus Group Discussion Pusdiklat Anggaran dan Perbendaharaan.

Gerson, R.F. (2001). Mengukur Kepuasan Pelanggan. Jakarta: PPM.

Hamdi, A. S. \& Bahruddin, E. (2014). Metode penelitian kuantitatif: aplikasi dalam pendidikan. Yogyakarta: Deepublish.

Inayah. (2020). Efektivitas KKP dalam meminimalisir kas menganggur bendahara pengeluaran satuan kerja di KPPN Blitar. Skripsi. Fakultas Ekonomi dan Bisnis, IAIN Tulungagung.

Kementerian Keuangan dan Institut Pertanian Bogor. (2013). Laporan Akhir Survey Opini Stakeholders Kementerian Keuangan RI. Bogor:Author.

Kotler, P. \& Keller, K. L. (2009). Marketing management (13th edition). New Jersey: Prentice Hall.

Kotler, P. (1998). Manajemen pemasaran (edisi ketujuh). Jakarta: PT. Gelora Aksara Pratama.

Kurniati, P. N. \& Nugroho, B.Y. (2019). Urgensi Pelaksanaan Sistem Cashless Government dalam Membangun Birokrasi yang Transparan dan Akuntabel. Jurnal Administrasi Publik, 9(2), 136-150

Kurniati, P. N., Nugroho, B.Y., \& Saragih, F.D. (2019). Implementation of the Government Credit Card Policy in 
the Ministry of Foreign Affairs of the Republic of Indonesia. ACHITS 2019, July 30-31, Surabaya.

Latu, T.M. \& Everett, A.M. (2000). Review of satisfaction research and measurement approaches. Wellington, New Zealand: Departement of Conservation.

Lesmana, B. (2018). Kartu Kredit Pemerintah, Model Baru Pengelolaan Keuangan Negara. Diakses dari https://www.kemenkeu.go.id.

Martilla, J.A. \& James, J.C. (1977). Importance-Performance Analysis. Journal of Marketing, 41(9), 77-79

Maulid, L. C. \& Sudibyo, Y. A. (2020). Kartu kredit pemerintah sebagai alat pembayaran belanja negara di Indonesia: permasalahan dan solusi. Akuntabel 17 (2). 301-313.

Novitasari, T., \& Halim, A. (2020). Analisis implementasi kartu kredit pemerintah (studi pada satuan kerja kementerian negara/lembaga di wilayah kerja KPPN Magelang). Accounting and Business Information Systems Journal, 8(2). Universitas Gadjah Mada

Peraturan Direktur Jenderal Perbendaharaan Nomor 17 Tahun 2017 Uji Coba Pembayaran Dengan Kartu Kredit Dalam Rangka Penggunaan Uang Persediaan. Direktorat Jenderal Perbendaharaan. Jakarta.

Peraturan Menteri Keuangan Nomor 178/PMK.05/2018 Perubahan PMK Nomor 190 Tahun 2012 tentang Tata Cara Pemabayaran APBN. Berita Negara Republik Indonesia Tahun 2018 Nomor 1736. Jakarta.

Peraturan Menteri Keuangan Nomor 196/PMK.05/2018 Tata Cara
Pembayaran dan Penggunaan Kartu Kredit Pemerintah. Berita Negara Republik Indonesia Tahun 2018 Nomor 1841. Jakarta.

Peraturan Pemerintah Nomor 45 Tahun 2013 Tata Cara Pelaksanaan Anggaran Pendapatan dan Belanja Negara. Lembaran Negara Republik Indonesia Tahun 2013 Nomor 103. Jakarta.

Peraturan Pemerintah Nomor 82 tahun 2012 Penyelenggaraan Sistem Dan Transaksi Elektronik. Lembaran Negara Republik Indonesia Tahun 2012 Nomor 189. Jakarta.

Pratama, S. A. \& Salam, A. (2019). Tinjauan yuridis pertanggungjawaban hukum kartu kredit pemerintah di Indonesia. Jurnal Hukum dan Pembangunan, 40(3), 710-742

Pujihastuti, I. (2010). Prinsip Penulisan Kuesioner Penelitian. CEFARS: Jurnal Agribisnis dan Pengembangan Wilayah, 2(1), 43-56 Sultan, M. A., Marsaoly, M. (2013). Kajian Tingkat Kepuasan Pengguna Infrastruktur Transportasi di Kabupaten Halmahera Utara. Jurnal Sipil Sains, 3(5), 63

Supranto, J. (2011). Pengukuran Tingkat Kepuasan Pelanggan untuk Meningkatkan Pangsa Pasar. Jakarta: Rineka Cipta.

Yola, M. \& Budianto, D. (2013). Analisis Kepuasan Konsumen Terhadap Kualitas Pelayanan dan Harga Produk Pada Supermarket dengan Menggunakan Metode Importance Performance Analysis. Jurnal Optimasi Sistem Industri, 12(12), 301-309.

Yulianti, D. \& Nurhazana. (2020). Efektivitas Kartu Kredit Pemerintah DalamMeningkatkan Transparansi 
Keuangan Negara pada KPPN

Dumai. Proceeding of National

Conference On Accounting and

Finance. Fakultas Ekonomi

Universitas Islam Indonesia. 